ISSN 1392-3196 / e-ISSN 2335-8947

Zemdirbyste-Agriculture, vol. 103, No. 3 (2016), p. 259-266

DOI 10.13080/z-a.2016.103.033

\title{
Assessment of greenhouse gas emission from life cycle of basic cereals production in Poland
}

\author{
Elżbieta WOJCIK-GRONT, Marta BLOCH-MICHALIK
}

Warsaw University of Life Sciences - SGGW

Nowoursynowska 159, 02-776 Warszawa, Poland

E-mail: ewojcik.gront@gmail.com

\begin{abstract}
The main objective of this study was to assess how much greenhouse gas (GHG) is emitted on average in the life cycle of basic cereals production in Poland. The crops included in the study are winter and spring wheat, winter and spring barley, winter and spring triticale, winter rye and spring oats. The data were taken from the national-scale, multi-environmental trials in 89 locations for years 2010-2015. The research also included comparison of two agrotechnical intensity levels: moderate with the use of nitrogen, potassium and phosphorus fertilization, insecticides, herbicides and pre-sowing treatment $-\mathrm{a}_{1}$, and intensive with the additional use of fungicides, growth regulator and higher nitrogen fertilization rate $-a_{2}$, for most cereal species. The results are expressed in the amount of greenhouse gas emitted per hectare and per kilogram of grain in cereal production and also contain the uncertainties attributed to the greenhouse gas emission calculated as propagation of error. The lowest emission for the levels $\mathrm{a}_{1}$ and $\mathrm{a}_{2}$ was estimated in the production of winter rye $\left(0.254 \pm 0.012\right.$ and $0.285 \pm 0.014 \mathrm{~kg} \mathrm{CO}_{2}$ eq. $\mathrm{kg}^{-1}$, respectively). The highest emission in the $\mathrm{a}_{1}$ level was estimated for spring triticale $\left(0.308 \pm 0.021 \mathrm{~kg} \mathrm{CO}_{2} \mathrm{eq}^{-\mathrm{kg}^{-1}}\right)$ and in the $\mathrm{a}_{2}$ level for spring wheat $\left(0.334 \pm 0.016 \mathrm{~kg} \mathrm{CO}\right.$ eq. $\left.\mathrm{kg}^{-1}\right)$. The conclusion of the study was that the main source of greenhouse gas emission from cereal production in Poland is nitrogen fertilizer use. It was also found that in most crops greenhouse gas emissions per unit of produced grain increased with the crop production intensification. It happens mostly due to the plant nitrogen over-fertilization.
\end{abstract}

Key words: carbon dioxide, emission uncertainty, nitrous oxide.

\section{Introduction}

Production of food for people and livestock has an environmental impact. In agriculture many management practices, like use of fertilizers and pesticides, machinery operations require energy and contribute to greenhouse gas (GHG) emission (Charles et al., 2006; Snyder et al., 2009). Crop production is a source of anthropogenic carbon dioxide, methane and nitrous oxide emission (Williams et al., 2010; Linquist et al., 2012). Greenhouse gases affect the atmosphere by chemical changes and therefore can cause climate change (Smith et al., 2007). According to the methodology developed by the Intergovernmental Panel on Climate Change, Poland's agricultural emission in 2013 accounted for $8.5 \%$ (30.1 $\mathrm{Mt} \mathrm{CO}_{2}$ eq.) of the national GHG emission (NIR 2015; Wójcik-Gront, 2015). That makes agriculture the third source of Poland's total GHG emission after energy and industrial processes sectors. The IPCC methodology takes into account methane and nitrous oxide emitted from agriculture leaving the $\mathrm{CO}_{2}$ from transport and energy inputs in agricultural supply and production for other sectors. That included would make agricultural contribution rise even more (CarlssonKanyama, González, 2009).
For comparison purposes the value of a gas emission is expressed as $\mathrm{CO}_{2}$ equivalent, it is the ratio of the Global Warming Potential (GWP) for one particle of this gas to one particle of $\mathrm{CO}_{2}$ (Forster et al., 2007). GWP depends on gas's absorption of radiation, absorbed wavelengths and a lifetime in the atmosphere. In the article, the GWP of $1 \mathrm{~kg}$ of $\mathrm{CH}_{4}$ and $1 \mathrm{~kg}$ of $\mathrm{N}_{2} \mathrm{O}$ is the equivalent to the GWPs of $25 \mathrm{~kg}$ and $298 \mathrm{~kg}$ of $\mathrm{CO}_{2}$, respectively.

The main objective of this study was to calculate how much $\mathrm{CO}_{2}$ equivalent is emitted on average in cereal crop production in Poland on 1 hectare of area planted and per one kilogram of grain. Cereals are a staple food in many developing and developed countries. The whole grain cereals are a rich source of carbohydrates, proteins, oils and also vitamins and minerals (Jonnalagadda et al., 2011). The cereals produced in Poland are (followed by their production in 2012 in thousand tones based on the data from the Central Statistical Office of Poland (GUS 2015 ): wheat -8608 , barley -4180 , triticale -3349 , rye -2888 and oat -1468 . Besides rye, all crops included in the study have been gaining in importance in recent decades. Greenhouse gases are emitted during combustion 
of fossil fuels used in the farm operations, agrochemicals production, packaging, storage and distribution and on top of that there is also soil-derived emission caused by applying some fertilizers. Polish economy started changing from centrally planned to free market with the end of communism period in 1989. Thus, the use of agrochemicals still might be not as high as in many developed countries. In the current study we attempted to assess the total emission during the cereal production and point out its major contributors.

\section{Materials and methods}

Greenhouse gas (GHG) emission calculations. The GHG emission in crop production is calculated as a sum of emission from preparing the seed, producing and applying mineral fertilizers and non-organic pesticides, and also fuel use in field operations. These are sources of emission for several gases: $\mathrm{CO}_{2}, \mathrm{~N}_{2} \mathrm{O}$ and $\mathrm{CH}_{4}$, whose amount is expressed as $\mathrm{CO}_{2}$ equivalent (eq.). In general, the total emission from one hectare of a crop was calculated as a sum of emission for each component, which came from the application rate multiplied by appropriate emission factor (EF). Application rate is the amount of the emission source: for example, kilograms of $\mathrm{N}$ fertilizer use. The emission factor is the amount of GHG produced by the application rate: for example, the amount of nitrous oxide from producing and applying kilogram of $\mathrm{N}$ fertilizer. The emission was calculated for each entry, i.e. each crop in each location and year. The estimated emission from one hectare for each entry was then divided by its experimental yield. Then the mean emission of one kilogram of each grain type with the uncertainty was estimated. In our paper the amount of emission source can be estimated precisely, from the experiments, unlike some emission factors.

Grain yield. The values of each application rate and the results of yield of winter and spring wheat, winter and spring barley, winter and spring triticale, winter rye and spring oats were taken from the Polish Post-Registration Variety Testing System (PRVTS) (Bujak et al., 2013). The PRVTS was established to evaluate the yield and other related traits of newly released cultivars through multienvironmental trials and give reliable recommendation to Polish farmers. The tests in the PRVTS in each location and for almost all crops are conducted for two agrotechnical intensity $\left(a_{1}\right.$ and $\left.a_{2}\right)$ levels in two replications based on the methodology elaborated by the PRVTS specialists. The first intensity level can be described as moderate and the second one as high. In the $\mathrm{a}_{1}$ level, mineral fertilization, seed preparation, herbicides and insecticides were used. In the $\mathrm{a}_{2}$ level, additional (about $40 \mathrm{~kg} \mathrm{ha}^{-1}$ ) nitrogen fertilization, foliar fertilization, fungicides and growth regulator were applied. The results on grain yield from the PRVTS are a reliable data source as they can be reproduced on a farm. There were 89 locations (Fig. 1) and 6 years (2010-2015) taken into account giving solid base for current Polish average emission estimation from basic cereal production. Using the available information the authors calculated average

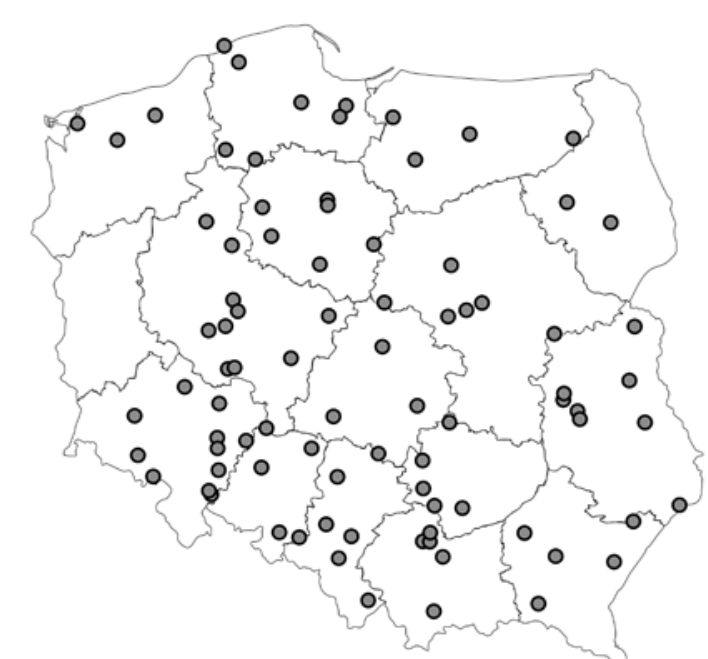

Note. Lines display administrative subdivisions of Poland.

Figure 1. Points show the locations of the experiments which took place between 2010 and 2015 in Poland

GHG emission per kilogram of each crop produced under varied soil and weather conditions for two agro-technical $\left(\mathrm{a}_{1}\right.$ and $\mathrm{a}_{2}$ ) levels.

Fuel (GHG) emission. The GHG emissions resulting from the combustion of fossil fuel use in field operations were estimated as an emission factor for one litre of diesel multiplied by the amount used for each field operation in conventional farming: cultivation, disking, harrowing, fertilizing, ploughing, pre-sowing treatment, sowing, chemical crop protection, harvesting, seed transport for each crop. The amount of diesel in basic cereal production was estimated based on average fuel consumption in field operations using conventional agricultural machinery selected based on Gaworski and Korpysz (2009). Furthermore, calculations of each treatment's effectiveness were carried out with a multi-stage computation model based on four standard assumptions about a random Polish farm: use of agricultural tractors with power: 59, 110 and $191 \mathrm{~kW}$, seasonal variability of every agricultural operation due to Polish climate, eight-hour working day and a basic farming area of about 100 hectares.

The estimates of the mean and the uncertainty of diesel use (DU) on necessary field operations are presented in Table 1. No straw management was included as it is considered as crop residues and might be handled in many ways including being left on the field. The density of a litre of diesel fuel is $0.84 \mathrm{~kg} \mathrm{dm}^{-3}$. Fuel net calorific value and emission factors are respectively $43.33 \mathrm{MJ} \mathrm{kg}^{-1}$ and $73.33 \mathrm{~kg} \mathrm{CO}_{2} \mathrm{GJ}^{-1}$ taken from The National Centre for Emissions Management (KOBiZE) for 2015. This means that combustion of each litre of diesel produces $2.67 \mathrm{~kg} \mathrm{CO}_{2}$ eq. The $\mathrm{GHG}$ emissions during diesel production and transportation might increase the diesel GHG contributions by up to 20\% (Maraseni et al., 2010). This was included in the calculations.

Fertilizers and pesticides GHG emission. For nutrient supply external inputs were used. These were synthetic nitrogen, phosphorus, potassium fertilizers and lime. The use of fertilizers is causing indirect emission 
Table 1. Diesel use (DU) for field operation in cereal production in Poland

\begin{tabular}{lcc}
\hline \multicolumn{1}{c}{ Field operation } & $\begin{array}{c}\mathrm{DU} \\
\mathrm{dm}^{3} \mathrm{ha}^{-1}\end{array}$ & $\begin{array}{c} \pm \Delta \mathrm{DU} \\
\mathrm{dm}^{3} \mathrm{ha}^{-1}\end{array}$ \\
\hline Cultivation & 5.00 & 0.50 \\
Disking & 4.67 & 0.47 \\
Harrowing & 2.90 & 0.29 \\
Fertilizing & 2.08 & 0.21 \\
Ploughing & 12.30 & 1.23 \\
Pre-sowing treatment & 3.94 & 0.39 \\
Sowing & 2.37 & 0.24 \\
Chemical treatment & 0.93 & 0.09 \\
Harvesting & 20.69 & 2.07 \\
\hline & $\mathrm{DU}$ & $\pm \Delta \mathrm{DU}$ \\
& $\mathrm{dm}^{3} \mathrm{t}^{-1} \mathrm{grain}^{3}$ & $\mathrm{dm}^{3} \mathrm{t}^{-1} \mathrm{grain}^{-1}$ \\
\hline Seed loading and transport & 2.05 & 0.21 \\
Yield transport & 1.74 & 0.17 \\
\hline
\end{tabular}

during their manufacture and processing. There is also a direct emission of $\mathrm{N}_{2} \mathrm{O}$ from the soil after applying $\mathrm{N}$ fertilizer and $\mathrm{CO}_{2}$ emission from lime use. Emission factors (EF) for manufacture of nitrogen, phosphorus and potassium fertilizers were adopted from Hughes et al. (2011). The data there were produced for the project for development of an Environmental Assessment Tool for Biomaterials funded by Defra by the National Non-Food Crops Centre (NNFCC). The same source was used to provide emission factors for pesticides. All fertilizers were given in terms of $\mathrm{N}, \mathrm{P}_{2} \mathrm{O}_{5}$ and $\mathrm{K}_{2} \mathrm{O}$ amounts. Emission from lime production was estimated based on emission factor from the inventory report methodology (De Klein et al., 2006). Nitrogen and lime applied to soil are source of further GHG emission (Table 2). In the case of cereals no organic manure was considered as its use is very rare. Other chemicals used in the crop production are plant growth regulators for plant cells stimulation or inhibition. The emission factor was applied from Berry et al. (2008). For foliar fertilization the authors took the mean value of all fertilizers. The pre-sowing chemical treatment has been estimated as a mean of all pesticides. The emission factors for each application rate in crop production are presented in Table 2 .

Table 2. Estimates of emission factors (EF) expressed in carbon dioxide $\left(\mathrm{CO}_{2}\right)$ equivalent (eq.) with the uncertainties emitted from agricultural chemicals and fuel use

\begin{tabular}{lccl}
\hline \multicolumn{1}{c}{ Emission source } & $\mathrm{EF} \mathrm{kg} \mathrm{CO}_{2} \mathrm{eq}_{\mathrm{kg}} \mathrm{k}^{-1}$ & $\pm \Delta \mathrm{EF} \mathrm{kg} \mathrm{CO}_{2}$ eq. $\mathrm{kg}^{-1}$ & \multicolumn{1}{c}{ Source of emission factor } \\
\hline Seed & 0.35 & 0.11 & author estimate \\
$\mathrm{N}$ fertilizer manufacture & 6.98 & 2.09 & Hughes et al., 2011 \\
$\mathrm{N}$ fertilizer upon application & 6.16 & 9.24 & De Klein et al., 2006 \\
$\mathrm{P}_{2} \mathrm{O}_{5}$ & 2.90 & 0.87 & Hughes et al., 2011 \\
$\mathrm{K}_{2} \mathrm{O}$ & 1.77 & 0.53 & Hughes et al., 2011 \\
Lime production & 0.72 & 0.22 & De Klein et al., 2006 \\
Lime upon application & 0.12 & 0.04 & NIR 2015 \\
Foliar fertilization & 5.94 & 1.78 & author estimate \\
Pre-sowing treatment & 4.46 & 1.34 & author estimate \\
Fungicides & 3.30 & 0.99 & Hughes et al., 2011 \\
Herbicides & 5.08 & 1.52 & Hughes et al., 2011 \\
Insecticides & 4.74 & 1.42 & Hughes et al., 2011 \\
Growth regulator & 4.70 & 1.41 & Berry et al., 2008 \\
Fuel use & 3.18 & 0.95 & author estimate \\
\hline
\end{tabular}

Soil. The soil carbon emission and sequestration were not included in the study as the carbon dioxide removed from the atmosphere while growing agricultural plants is reemitted during plant products consumption, decomposition or burning.

Electricity. GHG emissions due to the use of electricity for crop irrigation were not taken into consideration in this work. Irrigation in Polish cereal production is not very common. The main reason is the economy. The increase in yield is too low to justify investment cost and installation maintenance.

Application rates and uncertainty. Most of the soils in Poland are light, mostly sandy formations of rather low quality. The temperate climate of Poland is characterized by quite high weather variability, both seasonal and between years. Winters might be fairly wet and mild influenced by maritime climate or dry and cold when continental is predominant. Summers can also vary in air temperatures and rainfall between years. They may alternate between being hot and dry and cold and wet. This is why taking the results on grain yield from 6 years gives a reliable estimation on average cereal yield.

In the experiments for all cereal species mean applications levels for the fertilizers were $88.62 \mathrm{~kg}$ for $\mathrm{N} \mathrm{ha}^{-1} \mathrm{yr}^{-1}$ for the level $\mathrm{a}_{1}$ and 124.65 for the level $\mathrm{a}_{2}$, $49.57 \mathrm{~kg}$ for $\mathrm{P}_{2} \mathrm{O}_{5} \mathrm{ha}^{-1} \mathrm{yr}^{-1}$ and $85.05 \mathrm{~kg}$ for $\mathrm{K}_{2} \mathrm{O} \mathrm{ha}{ }^{-1}$ $\mathrm{yr}^{-1}$ for both management intensities. Lime is applied in the same amount $(750 \mathrm{~kg})$ every four years, regardless of the cultivated cereal. In the $\mathrm{a}_{2}$ level of agro-technical intensity, average foliar fertilization was $4.59 \mathrm{~kg} \mathrm{ha}^{-1}$. Average herbicide and insecticide use was 1.03 and $0.17 \mathrm{~kg} \mathrm{ha}^{-1}$, respectively. Fungicides were used only in the $\mathrm{a}_{2}$ level of agro-technical intensity in the mean amount of $1.25 \mathrm{~kg} \mathrm{ha}^{-1}$. Level of chemical seed protection was on average $0.33 \mathrm{~kg} \mathrm{ha}^{-1}$ and growth regulator used only in 
the $a_{2}$ level of intensity was applied on average in the amount of $0.50 \mathrm{~kg} \mathrm{ha}^{-1}$.

Estimated average application rates expressed in kilograms per hectare with their uncertainties (estimated based on $68 \%$ confidence interval) in Polish cereal production are presented in Table 3. The uncertainties of results were calculated according to the error propagation equation:

$$
s_{f}=\sqrt{\left(\frac{\partial f}{\partial x_{1}}\right)^{2} s_{x_{1}}^{2}+\left(\frac{\partial f}{\partial x_{2}}\right)^{2} s_{x_{2}}^{2}+\ldots+\left(\frac{\partial f}{\partial x_{n}}\right)^{2} s_{x_{n}}^{2}},
$$

where $\mathrm{s}_{\mathrm{f}}$ represents the uncertainty of the function $\mathrm{f}\left(\mathrm{x}_{1}, \ldots, \mathrm{x}_{\mathrm{n}}\right), \mathrm{s}_{\mathrm{x}}$ - the uncertainty of corresponding variable $\mathrm{x}$. The same method has been used in Polish inventory report NIR so far. Studies by Wójcik-Gront and Gront
(2014) showed that this method of assessing uncertainty is sufficient for this kind of study.

\section{Results and discussion}

Emission from production of grain from one hectare and per one kilogram of grain for species of cereal in two agro-technical intensity levels is presented in Figure 2. According to the estimation, the lowest emission for the levels $a_{1}$ and $a_{2}$ was from production of winter rye $\left(0.254 \pm 0.012\right.$ and $0.285 \pm 0.014 \mathrm{~kg} \mathrm{CO}_{2}$ eq. $\mathrm{kg}^{-1}$, respectively). The highest emission in the level $\mathrm{a}_{1}$ was from spring triticale $\left(0.308 \pm 0.021 \mathrm{~kg} \mathrm{CO} 2\right.$ eq. $\left.\mathrm{kg}^{-1}\right)$ and from spring wheat $\left(0.334 \pm 0.016 \mathrm{~kg} \mathrm{CO}_{2}\right.$ eq. $\left.\mathrm{kg}^{-1}\right)$ production in the $\mathrm{a}_{2}$ level.

Table 3. Average application rates and yield in the experiments on basic cereal production for the $\mathrm{a}_{1}$ and $\mathrm{a}_{2}$ agrotechnical intensity levels

\begin{tabular}{|c|c|c|c|c|c|c|c|c|c|}
\hline & & \multicolumn{2}{|c|}{ Wheat } & \multicolumn{2}{|c|}{ Barley } & \multicolumn{2}{|c|}{ Triticale } & \multirow{2}{*}{$\begin{array}{c}\text { Rye } \\
\text { winter }\end{array}$} & \multirow{2}{*}{$\begin{array}{c}\text { Oats } \\
\text { spring }\end{array}$} \\
\hline & & winter & spring & winter & spring & winter & spring & & \\
\hline \multicolumn{10}{|c|}{$\mathrm{m}^{-2}$} \\
\hline Seeds & $\mathrm{a}_{1}, \mathrm{a}_{2}$ & $426 \pm 32$ & $475 \pm 32$ & $380 \pm 33$ & $310 \pm 22$ & $392 \pm 36$ & $481 \pm 47$ & $287 \pm 39$ & $495 \pm 42$ \\
\hline \multicolumn{10}{|c|}{$\mathrm{kg} \mathrm{ha}^{-1}$} \\
\hline $\mathrm{N}$ & $a_{1}$ & $\begin{array}{c}107.30 \pm \\
20.09\end{array}$ & $\begin{array}{c}88.38 \pm \\
19.90\end{array}$ & $\begin{array}{c}82.73 \pm \\
21.03\end{array}$ & $\begin{array}{c}75.38 \pm \\
26.08\end{array}$ & $\begin{array}{c}96.68 \pm \\
18.78\end{array}$ & $\begin{array}{c}91.10 \pm \\
25.31\end{array}$ & $\begin{array}{c}83.10 \pm \\
18.35\end{array}$ & $\begin{array}{c}84.27 \pm \\
24.16\end{array}$ \\
\hline $\mathrm{N}$ & $\mathrm{a}_{2}$ & $\begin{array}{c}147.30 \pm \\
20.09\end{array}$ & $\begin{array}{c}128.18 \pm \\
20.04\end{array}$ & $\begin{array}{c}122.73 \pm \\
21.03\end{array}$ & $\begin{array}{c}115.01 \pm \\
25.95\end{array}$ & $\begin{array}{c}136.68 \pm \\
18.78\end{array}$ & $\begin{array}{c}99.64 \pm \\
26.74\end{array}$ & $\begin{array}{c}123.03 \pm \\
18.23\end{array}$ & - \\
\hline $\mathrm{P}_{2} \mathrm{O}_{5}$ & $a_{1}, a_{2}$ & $\begin{array}{c}54.22 \pm \\
4.02\end{array}$ & $\begin{array}{c}48.71 \pm \\
20.38\end{array}$ & $\begin{array}{c}51.07 \pm \\
17.05\end{array}$ & $\begin{array}{c}47.29 \pm \\
20.79\end{array}$ & $\begin{array}{c}50.25 \pm \\
18.43\end{array}$ & $\begin{array}{c}48.26 \pm \\
21.75\end{array}$ & $\begin{array}{c}47.59 \pm \\
20.73\end{array}$ & $\begin{array}{c}49.32 \pm \\
22.10\end{array}$ \\
\hline $\mathrm{K}_{2} \mathrm{O}$ & $a_{1}, a_{2}$ & $\begin{array}{c}88.38 \pm \\
6.55\end{array}$ & $\begin{array}{c}85.06 \pm \\
26.15\end{array}$ & $\begin{array}{c}87.28 \pm \\
22.09\end{array}$ & $\begin{array}{c}81.35 \pm \\
29.53\end{array}$ & $\begin{array}{c}82.17 \pm \\
26.91\end{array}$ & $\begin{array}{c}89.66 \pm \\
25.02\end{array}$ & $\begin{array}{c}80.74 \pm \\
26.07\end{array}$ & $\begin{array}{c}85.74 \pm \\
29.56\end{array}$ \\
\hline $\begin{array}{l}\text { Foliar } \\
\text { fertilization }\end{array}$ & $a_{2}$ & $\begin{array}{c}5.22 \pm \\
6.00\end{array}$ & $\begin{array}{c}5.89 \pm \\
6.85\end{array}$ & $\begin{array}{c}4.76 \pm \\
4.74\end{array}$ & $\begin{array}{c}6.23 \pm \\
7.41\end{array}$ & $\begin{array}{c}5.48 \pm \\
6.09\end{array}$ & $\begin{array}{c}3.10 \pm \\
3.98\end{array}$ & $\begin{array}{c}5.16 \pm \\
5.28\end{array}$ & $\begin{array}{c}0.87 \pm \\
3.72\end{array}$ \\
\hline $\begin{array}{l}\text { Pre-sowing } \\
\text { treatment }\end{array}$ & $a_{1}, a_{2}$ & $\begin{array}{c}0.35 \pm \\
0.03\end{array}$ & $\begin{array}{c}0.39 \pm \\
0.03\end{array}$ & $\begin{array}{l}0.31 \pm \\
0.03\end{array}$ & $\begin{array}{c}0.25 \pm \\
0.02\end{array}$ & $\begin{array}{c}0.32 \pm \\
0.03\end{array}$ & $\begin{array}{c}0.39 \pm \\
0.04\end{array}$ & $\begin{array}{c}0.23 \pm \\
0.03\end{array}$ & $\begin{array}{c}0.40 \pm \\
0.03\end{array}$ \\
\hline Herbicides & $a_{1}, a_{2}$ & $\begin{array}{c}1.36 \pm \\
1.08\end{array}$ & $\begin{array}{c}0.8 \pm \\
0.7\end{array}$ & $\begin{array}{c}1.13 \pm \\
0.99\end{array}$ & $\begin{array}{c}0.78 \pm \\
0.66\end{array}$ & $\begin{array}{c}1.15 \pm \\
0.84\end{array}$ & $\begin{array}{c}0.80 \pm \\
0.68\end{array}$ & $\begin{array}{l}1.28 \pm \\
0.93\end{array}$ & $\begin{array}{c}0.92 \pm \\
0.75\end{array}$ \\
\hline Insecticides & $a_{1}, a_{2}$ & $\begin{array}{c}0.18 \pm \\
0.27\end{array}$ & $\begin{array}{l}0.21 \pm \\
0.32\end{array}$ & $\begin{array}{c}0.13 \pm \\
0.23\end{array}$ & $\begin{array}{c}0.17 \pm \\
0.29\end{array}$ & $\begin{array}{c}0.16 \pm \\
0.30\end{array}$ & $\begin{array}{c}0.19 \pm \\
0.25\end{array}$ & $\begin{array}{c}0.09 \pm \\
0.17\end{array}$ & $\begin{array}{c}0.26 \pm \\
0.42\end{array}$ \\
\hline Fungicides & $\mathrm{a}_{2}$ & $\begin{array}{l}1.69 \pm \\
0.55\end{array}$ & $\begin{array}{c}1.37 \pm \\
0.37\end{array}$ & $\begin{array}{l}1.37 \pm \\
0.43\end{array}$ & $\begin{array}{c}1.33 \pm \\
0.37\end{array}$ & $\begin{array}{c}1.54 \pm \\
0.46\end{array}$ & $\begin{array}{c}1.24 \pm \\
0.47\end{array}$ & $\begin{array}{l}1.48 \pm \\
0.76\end{array}$ & $\begin{array}{c}0.02 \pm \\
0.11\end{array}$ \\
\hline $\begin{array}{l}\text { Growth } \\
\text { regulator }\end{array}$ & $\mathrm{a}_{2}$ & $\begin{array}{c}0.78 \pm \\
0.06\end{array}$ & $\begin{array}{c}0.56 \pm \\
0.04\end{array}$ & $\begin{array}{c}0.71 \pm \\
0.06\end{array}$ & $\begin{array}{c}0.48 \pm \\
0.03\end{array}$ & $\begin{array}{c}0.73 \pm \\
0.07\end{array}$ & $\begin{array}{c}0.05 \pm \\
0.00\end{array}$ & $\begin{array}{c}0.69 \pm \\
0.09\end{array}$ & $\begin{array}{c}0.01 \pm \\
0.00\end{array}$ \\
\hline Lime & $a_{1}, a_{2}$ & $\begin{array}{c}187.50 \pm \\
9.38\end{array}$ & $\begin{array}{c}187.5 \pm \\
9.38 \\
\end{array}$ & $\begin{array}{c}187.50 \pm \\
9.38 \\
\end{array}$ & $\begin{array}{c}187.50 \pm \\
9.38 \\
\end{array}$ & $\begin{array}{c}187.5 \pm \\
9.38 \\
\end{array}$ & $\begin{array}{c}187.50 \pm \\
9.38\end{array}$ & $\begin{array}{c}187.5 \pm \\
9.38 \\
\end{array}$ & $\begin{array}{c}187.50 \pm \\
9.38 \\
\end{array}$ \\
\hline \multicolumn{10}{|c|}{$\mathrm{dm}^{3} \mathrm{ha}^{-1}$} \\
\hline Fuel use & $a_{1}, a_{2}$ & $\begin{array}{c}68.84 \pm \\
3.44\end{array}$ & $\begin{array}{c}66.50 \pm \\
3.32 \\
\end{array}$ & $\begin{array}{c}67.9 \pm \\
3.4 \\
\end{array}$ & $\begin{array}{c}66.83 \pm \\
3.34 \\
\end{array}$ & $\begin{array}{c}67.96 \pm \\
3.40\end{array}$ & $\begin{array}{c}66.42 \pm \\
3.32 \\
\end{array}$ & $\begin{array}{c}67.68 \pm \\
3.38 \\
\end{array}$ & $\begin{array}{c}66.70 \pm \\
3.33 \\
\end{array}$ \\
\hline \multicolumn{10}{|c|}{$\mathrm{t} \mathrm{ha}^{-1}$} \\
\hline Yield & $a_{1}$ & $\begin{array}{c}8.02 \pm \\
1.70\end{array}$ & $\begin{array}{c}6.68 \pm \\
1.31\end{array}$ & $\begin{array}{c}7.48 \pm \\
1.76\end{array}$ & $\begin{array}{c}6.87 \pm \\
1.65\end{array}$ & $\begin{array}{c}7.51 \pm \\
1.65\end{array}$ & $\begin{array}{c}6.63 \pm \\
1.27\end{array}$ & $\begin{array}{c}7.35 \pm \\
1.50\end{array}$ & $\begin{array}{c}6.79 \pm \\
1.54\end{array}$ \\
\hline Yield & $\mathrm{a}_{2}$ & $\begin{array}{c}9.29 \pm \\
1.89\end{array}$ & $\begin{array}{c}7.74 \pm \\
1.52\end{array}$ & $\begin{array}{c}8.58 \pm \\
1.97\end{array}$ & $\begin{array}{c}7.75 \pm \\
1.72\end{array}$ & $\begin{array}{c}9.32 \pm \\
7.60\end{array}$ & $\begin{array}{c}7.34 \pm \\
1.37\end{array}$ & $\begin{array}{c}8.57 \pm \\
1.54\end{array}$ & - \\
\hline
\end{tabular}

The results obtained for two agro-technical intensities $a_{1}$ and $a_{2}$ were compared using two-sample t-tests for a difference in mean involving paired samples. The $p$-values show significant differences for all crops examined for two agro-technical intensities. The comparison of calculated confidence intervals showed that at the $\mathrm{a}_{1}$ agro-technical level emission from winter rye was lower than for other crops. That was due to lower $\mathrm{N}$ fertilizer application rate and relatively high yield. In the $\mathrm{a}_{2}$ level, the confidence intervals overlapped.

In almost all cereals (except spring triticale) with increased intensity comes higher emission per grain 


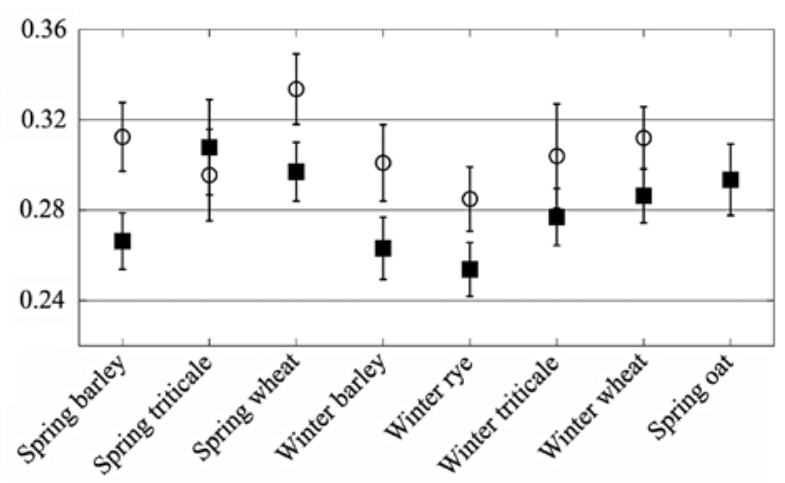

Note. The black squares show results for moderate intensity of agro-technical treatment $\left(\mathrm{a}_{1}\right)$ and circles for the intensive one $\left(a_{2}\right)$.

Figure 2. Emission in $\mathrm{kg}$ carbon dioxide $\left(\mathrm{CO}_{2}\right)$ equivalent (eq.) from production of a kilogram of grain and the uncertainty calculated from propagation of error

unit. In case of spring triticale in many locations the use of nitrogen fertilization, the biggest emission impact, was not increased significantly at the $a_{2}$ agro-technical level in comparison to $a_{1}$. But there were used additional fungicides and growth regulator. At the same time, the mean yield of spring triticale in a more intensive agrotechnical intensity $\left(a_{2}\right)$ was higher by $10 \%$. That is lower than the mean yield increase for other crops (14\%). This proves that unrestricted increase in the use of nitrogen is not always the way to improve yield effectiveness as it may lead to over-fertilization (Charles et al., 2006).

The dominant factor in emission per grain unit is the use of nitrogen for both agro-technical intensities (from $58.43 \%$ to $70.52 \%$ ). Then the emission from fuel use comes into the picture as a second main contributor (from $8.30 \%$ to $12.70 \%$ ). Then there are other fertilizers. The chemical protection impact on the emission is not very high as the application rates are approximately 10fold lower than those of nitrogen.

The comparison between different parts of Poland based on the location of the experiments showed that on average higher emission occurred in Pomeranian region (northwest part of Poland) due to higher $\mathrm{N}$ application rate than in the rest of the country. The lowest emission was noticed in Lakeland area (northeast Poland) because the grain yield was relatively high and the use of nitrogen fertilizer low (on average $50 \mathrm{~kg}$ lower than in Pomeranian region for each intensity level respectively). The average emission between years for all crops in the whole country was the lowest for years 2014 and 2015. It was $0.04 \mathrm{CO}_{2}$ eq. $\mathrm{kg}^{-1}$ less than for 2011 , when the average emission was the highest. It is a consequence of higher cereal yield in these years in the whole country in comparison to previous years rather than because of the difference between the average input of nitrogen fertilization (only $6.5 \mathrm{~kg} \mathrm{ha}^{-1}$ ) between the years with lowest and highest cereal emission. The detailed comparison of emission per grain unit between years and different parts of Poland might need further investigation.
In this paper we assessed GHG emissions from wheat, rye, barley, oats, triticale and maize production in Poland. The study was based on estimated mean values for application rates in cereal production and emission factors taken from literature and estimated by authors. The main contributor to GHG emission from cereal cultivation is nitrogen fertilizer use. The results also suggest that emission per yield unit can be higher with production intensification, when excessive nitrogen fertilizing is used. The work by Burney et al. (2009) and Grassini and Cassman (2012) has proved that GHG emission can be mitigated by agricultural intensification with the sufficient increase in yield.

There are several studies on GHG emission in cereal production in Europe and other parts of the world. Berry et al. (2008) reported that production of $1 \mathrm{~kg}$ of wheat in the UK was associated with emission of $0.408 \mathrm{~kg} \mathrm{CO}$ eq. However, Berry included straw management and grain drying. Hughes et al. (2011) estimated that the inputs to growing winter barley in the United Kingdom release $2617 \mathrm{~kg} \mathrm{CO}$ eq. ha ${ }^{-1}$. The corresponding emission for spring barley, where nitrogen inputs are smaller was $2099 \mathrm{~kg} \mathrm{CO}_{2}$ eq. ha- ${ }^{-1}$ Taking the yield into equation (winter barley $-7.8 \mathrm{t} \mathrm{ha}^{-1}$ and spring barley - $7.0 \mathrm{t} \mathrm{ha}^{-1}$ ) the outcome is $335 \mathrm{~kg} \mathrm{CO}_{2}$ eq. $\mathrm{t}^{-1}$ for winter barley and $300 \mathrm{~kg} \mathrm{CO}_{2}$ eq. $\mathrm{t}^{-1}$ for spring barley. The results are compared to ours at the intensity level $\mathrm{a}_{2}$ (similar $\mathrm{N}$ application rate and the use of fungicides) but in their work the $\mathrm{N}$ rate for winter barley is even higher and for spring barley smaller. Rajaniemi et al. (2011) in the conventional production reported the following values of GHG emission in Finland: $0.57 \mathrm{~kg} \mathrm{CO}$ eq. $\mathrm{kg}^{-1}$ for oat, $0.57 \mathrm{~kg} \mathrm{CO}_{2}$ eq. $\mathrm{kg}^{-1}$ for barley, $0.59 \mathrm{~kg} \mathrm{CO}_{2}$ eq. $\mathrm{kg}^{-1}$ for wheat and $0.87 \mathrm{~kg} \mathrm{CO}_{2}$ eq. $\mathrm{kg}^{-1}$ for rye. These values are higher than in our research but the yield reported by Rajaniemi et al. (2011) was two-fold lower than in the experiments used in this work. Van Stappen et al. (2015) reported the value $0.349 \mathrm{~kg} \mathrm{CO}_{2}$ eq. $\mathrm{kg}^{-1}$ in wheat production in Belgium. The authors included machinery production and straw management in the calculations. The grain yield was comparable to our work $\left(8.5 \mathrm{tha}^{-1}\right)$. Another work (Charles et al., 2006) from Switzerland stated that the environmental impact of standard treatment of winter wheat per ton of grain with $\mathrm{N}$ application rate $140 \mathrm{~kg}$ $\mathrm{ha}^{-1}$ was $381 \mathrm{~kg} \mathrm{CO}_{2}$ eq., while the yield was around $6.1 \mathrm{t} \mathrm{ha}^{-1}$. The work takes into account also production and transport of machinery for wheat cultivation. Jensen and Arlbjørn (2014) while calculating carbon footprint of bread production in Denmark obtained GHG emission of $223 \mathrm{~g} \mathrm{CO}_{2}$ eq. $\mathrm{kg}^{-1}$ for producing grain of rye and 298 for spring barley. Ali et al. (2015) performed calculation on GHG emission from durum wheat production in Italy resulting in 1172.8 or $0.244 \mathrm{CO}_{2}$ eq. $\mathrm{kg}^{-1}$ with lower $\mathrm{N}$ rates and lower yield than in our work.

Biswas et al. (2008) reported $304 \mathrm{~kg} \mathrm{CO}$ eq. emitted during the production and delivery of 1 tonne of wheat to port in Australia. The calculation also contains estimation of a post-farm stage, i.e. wheat storage and 
transport to port $(11 \%$ of emission from the life cycle assessment). Yan et al. (2015) estimated that the product carbon footprint in terms of grain produced was 0.66 $\pm 0.03 \mathrm{t} \mathrm{CO}_{2}$ eq. $\mathrm{t}^{-1}$ for wheat in China and the use of synthetic nitrogen fertilizers contributed $79 \%$ of the total carbon footprints as amounting to around $300 \mathrm{~kg} \mathrm{ha}^{-1} \mathrm{~N}$.

The results from different regions on $\mathrm{GHG}$ emission in cereal production are comparable with the outcome from our study especially taking into account the uncertainty analysis performed at the large dataset used.

There is one main outcome of the cited studies and our work. The main contributor of GHG emission from the life cycle assessment of rain-fed cereal production is nitrogen fertilizer. The GHG emission comes from the fertilizer production and its application.

After the Second World War humanity started using agrochemicals on a mass scale. At the end of the last century the yield of rice, wheat and corn per unit of area increased several fold due to biological development and use of fertilizers, pesticides and energy. There are studies where the reported $\mathrm{N}$ application rate is as high as $750 \mathrm{~kg} \mathrm{ha}^{-1}$ (Liu et al., 2016). However, further unconditioned agro-technical intensification may change soil ability to produce yield (Yue et al., 2012). At the same time, achieving high yields, together, with relatively low emission, is possible when applied inputs are precisely managed in time and space (Linquist et al., 2012). To preserve and improve soil fertility in European countries an agricultural integrated production was implemented (Integrated Production..., 2004). It is a sustainable farming system that produces high quality products by first of all using natural resources and then polluting inputs if necessary. The use of biological, technical and chemical inputs must also take into consideration the protection of the environment.

\section{Conclusion}

Low productivity crop is not environmentally beneficial. In temperate climate of Europe, the yield of cereals strongly depends on nitrogen fertilization. However, the increased use of nitrogen $(\mathrm{N})$ fertilizer requires adequate increase in yield otherwise it causes redundant emissions and burden to the environment.

In this paper, we showed that: 1) $\mathrm{N}$ fertilizer is the main contributor to greenhouse gas (GHG) emission from the cereal production, 2) an increase in $\mathrm{N}$ fertilizer use (in the paper $40 \mathrm{~kg}$ ) leads to higher emission per area unit so it should translate into equally high yield increase otherwise might lead to increased emission per yield unit, which should not be the case, 3) emission per cereal species was similar depending only on agro-technical intensity level.

Received 19022016

Accepted 13062016

\section{References}

Ali S. A., Tedone L., De Mastro G. 2015. Optimization of the environmental performance of rainfed durum wheat by adjusting the management practices. Journal of Cleaner Production, 87: 105-118 http://dx.doi.org/10.1016/j.jclepro.2014.09.029

Berry P. M., Kindred D. R., Paveley N. D. 2008. Quantifying the effects of fungicides and disease resistance on greenhouse gas emissions associated with wheat production. Plant Pathology, 57: 1000-1008 http://dx.doi.org/10.1111/j.1365-3059.2008.01899.x

Biswas W. K., Barton L., Carter D. 2008. Global warming potential of wheat production in Western Australia: a life cycle assessment. Water and Environment Journal, 22: 206-216 http://dx.doi.org/10.1111/j.1747-6593.2008.00127.x

Bujak H., Tratwal G., Weber R., Kaczmarek J., Gacek E. 2013. An analysis of spatial similarity in the variability of yields of winter wheat (Triticum aestivum L.) cultivars in Western Poland. Zemdirbyste-Agriculture, 100 (3): 311-316 http://dx.doi.org/10.13080/z-a.2013.100.040

Burney J. A., Davis S. J., Lobell D. B. 2009. Greenhouse gas mitigation by agricultural intensification. PNAS, 107 (26): 12052-12057

http://dx.doi.org/10.1073/pnas.0914216107

Carlsson-Kanyama A., González A. D. 2009. Potential contributions of food consumption patterns to climate. American Journal of Clinical Nutrition, 89 (5): 1704S-1709S

http://dx.doi.org/10.3945/ajen.2009.26736AA

Charles R., Jolliet O., Gaillard G., Pellet D. 2006. Environmental analysis of intensity level in wheat crop production using life cycle assessment. Agriculture Ecosystems and Environment, 113 (1-4): 216-225 http://dx.doi.org/10.1016/j.agee.2005.09.014

De Klein C., Novoa R. S. A., Ogle S., Smith K. A., Rochette P., Wirth T. C., McConkey B. G., Mosier A., Rypdal K. 2006. $\mathrm{N}_{2} \mathrm{O}$ emissions from managed soils, and $\mathrm{CO}_{2}$ emissions from lime and urea application. 2006 IPCC Guidelines for National Greenhouse Gas Inventories. Agriculture, Forestry and Other Land Use. International Panel on Climate Change

Forster P., Ramaswamy V., Artaxo P., Berntsen T., Betts R., Fahey D. W., Haywood J., Lean J., Lowe D. C., Myhre G., Nganga J., Prinn R., Raga G., Schulz M., Van Dorland R. 2007. Changes in atmospheric constituents and in radiative forcing. Solomon S. et al. (eds.). Climate Change 2007: The Physical Science Basis. Contribution of Working Group I to the Fourth Assessment Report of the Intergovernmental Panel on Climate Change. Cambridge, UK/New York, USA

Gaworski M., Korpysz K. 2009. Agricultural engineering. Mechanizacja rolnictwa, vol. 2. Warszawa, Poland

Grassini P., Cassman K. G. 2012. High-yield maize with large net energy yield and small global warming intensity. PNAS, 109 (4): 1074-1079 http://dx.doi.org/10.1073/pnas.1116364109

GUS 2015. Statistical yearbook on agriculture. Central Statistical Office of Poland $<$ http://stat.gov.pl/en/ $>$

Hughes D. J., West J. S., Atkins S. D., Gladders P., Jeger M. J., Fitt B. DL. 2011. Effects of disease control by fungicides on greenhouse gas emissions by UK arable crop production. Pest Management Science, 67 (9): 1082-1092 http://dx.doi.org/10.1002/ps.2151 
Integrated Production Principles and Technical Guidelines. 2004. Boller E. F. et al. (eds). IOBC wprs Bulletin, 27 (2)

Jensen J. K., Arlbjørn J. S. 2014. Product carbon footprint of rye bread. Journal of Cleaner Production, 82: 45-57 http://dx.doi.org/10.1016/j.jclepro.2014.06.061

Jonnalagadda S. S., Harnack L., Liu R. H., McKeown N., Seal C., Liu S., Fahey G. C. 2011. Putting the whole grain puzzle together: health benefits associated with whole grains summary of American Society for Nutrition 2010 Satellite Symposium. Journal of Nutrition, 141 (5): 1011S-1022S http://dx.doi.org/10.3945/jn.110.132944

KOBiZE 2015. Database of National Administration of Emission Trading Scheme containing information on emissions of GHG and other pollutants. The National Centre for Emissions Management $<\mathrm{http}$ ://www.kobize. $\mathrm{pl} / \mathrm{en}>$

Linquist B., van Groenigen K. J., Adviento-Borbe M. A., Pittelkow C., van Kessel C. 2012. An agronomic assessment of greenhouse gas emissions from major cereal crops. Global Change Biology, 18 (1): 194-209 http://dx.doi.org/10.1111/j.1365-2486.2011.02502.x

Liu H., Wang Z., Yu R., Li F., Li K., Cao H., Yang N., Li M., Dai J., Zan Y., Li Q., Xue Ch., He G., Huang D., Huang M., Liu J., Qiu W., Zhao H., Mao H. 2016. Optimal nitrogen input for higher efficiency and lower environmental impacts of winter wheat production in China. Agriculture, Ecosystems and Environment, 224: 1-11 http://dx.doi.org/10.1016/j.agee.2016.03.022

Maraseni T. N., Cockfield G., Maroulis J. 2010. An assessment of greenhouse gas emissions: implications for the Australian cotton industry. The Journal of Agricultural Science, 148 (5): 501-510 http://dx.doi.org/10.1017/S002185960999058X

NIR 2015. Poland's National Inventory Report 2015, Greenhouse Gas Inventory for 1988-2015. Submission under the UN Framework Convention on Climate Change and its Kyoto Protocol. Warszawa, Poland

Rajaniemi M., Mikkola H., Ahokas J. 2011. Greenhouse gas emissions from oats, barley, wheat and rye production. Agronomy Research. Biosystem Engineering 1 (spec. iss.): $189-195$

Smith P., Martino D., Cai Z., Gwary D., Janzen H., Kumar P., McCarl B., Ogle S., O'Mara F., Rice C., Scholes B., Sirotenko O. 2007. Agriculture. Climate Change 2007: Mitigation. Contribution of Working Group III to the Fourth Assessment Report of the Intergovernmental Panel on Climate Change. Cambridge, UK/New York, USA

Snyder C. S., Bruulsema T. W., Jensen T. L., Fixen P. E. 2009. Review of greenhouse gas emissions from crop production systems and fertilizer management effects. Agriculture, Ecosystems and Environment, 133: 247-266 http://dx.doi.org/10.1016/j.agee.2009.04.021

Van Stappen F., Loriers A., Mathot M., Planchon V., Stilmant D., Debode F. 2015. Organic versus conventional farming: the case of wheat production in Wallonia (Belgium). Agriculture and Agricultural Science Procedia, 7: 272-279 http://dx.doi.org/10.1016/j.aaspro.2015.12.047

Williams A. G., Audsley E., Sandars D. L. 2010. Environmental burdens of producing bread wheat, oilseed rape and potatoes in England and Wales using simulation and system modelling. International Journal of Life Cycle Assessment, 15: 855-868

http://dx.doi.org/10.1007/s11367-010-0212-3
Wójcik-Gront E. 2015. Territorial analysis of agricultural greenhouse gas emission in Poland. Applied Ecology and Environmental Research, 13 (2): 417-425 http://dx.doi.org/10.5367/oa.2014.0155

Wójcik-Gront E., Gront D. 2014. Assessing uncertainty in the Polish agricultural greenhouse gas emission inventory using Monte Carlo simulation. Outlook on Agriculture, 43 (1): 61-65

Yan M., Cheng K., Luo T., Yan Y., Pan G., Rees R. M. 2015. Carbon footprint of grain crop production in China - based on farm survey data. Journal of Cleaner Production, 104: $130-138$ http://dx.doi.org/10.1016/j.jclepro.2015.05.058

Yue S., Meng, Q., Zhao R., Ye Y., Zhang F., Cui Z., Chen X. 2012. Change in nitrogen requirement with increasing grain yield for winter wheat. Agronomy Journal, 104: $1687-1693$ http://dx.doi.org/10.2134/agronj2012.0232 
ISSN 1392-3196 / e-ISSN 2335-8947

Zemdirbyste-Agriculture, vol. 103, No. 3 (2016), p. 259-266

DOI 10.13080/z-a.2016.103.033

\title{
Šiltnamio efektą sukeliančių dujų emisijos per pagrindinių rūšių javų auginimo ciklą ịvertinimas Lenkijoje
}

\author{
E. Wojcik-Gront, M. Bloch-Michalik \\ Varšuvos gyvybės mokslų universitetas, Lenkija
}

\begin{abstract}
Santrauka
Tyrimo tikslas - ịvertinti, kiek šiltnamio efektą sukeliančių dujų vidutiniškai išsiskiria per pagrindinių rūšių javų auginimo ciklą Lenkijoje. Tyrimas atliktas su žieminiais ir vasariniais kviečiais, žieminiais ir vasariniais miežiais, žieminiais ir vasariniais kvietrugiais, žieminiais rugiais ir vasarinemis avižomis. Duomenys buvo paimti iš nacionalinių bandymų, atliktų skirtingose aplinkose 89 vietovése 2010-2015 m. Tyrimo metu taip pat buvo lyginti du agrotechninio intensyvumo lygiai: $a_{1}$ - vidutinis, tręšiant azoto, kalio ir fosforo trąšomis, naudojant insekticidus, herbicidus ir taikant priešsèjinị žemès dirbimą, ir $\mathrm{a}_{2}$ - intensyvus, papildomai naudojant fungicidus, augimo reguliatorius ir daugumą rūšių javų tręšiant didesnèmis normomis azoto. Rezultatai išreikšti šiltnamio efektą sukeliančių dujų kiekiu hektarui arba kilogramui grūdų, taip pat susieti su neapibrèžtimis - paklaidomis. Mažiausia emisija taikant $a_{1}$ ir $a_{2}$ agrotechniką nustatyta žieminiuose rugiuose (atitinkamai 0,254 $\pm 0,012$ ir 0,285 $\left.\pm 0,014 \mathrm{~kg} \mathrm{CO}_{2} \mathrm{ekv} . \mathrm{kg}^{-1}\right)$. Didžiausia emisija taikant a nustatyta vasariniuose kvietrugiuose $(0,308 \pm 0,021 \mathrm{~kg}$ $\mathrm{CO}_{2}$ ekv. kg-1), $\mathrm{a}_{2}$ - vasariniuose kviečiuose $\left(0,334 \pm 0,016 \mathrm{~kg} \mathrm{CO}_{2} \mathrm{ekv} . \mathrm{kg}^{-1}\right)$. Padaryta išvada, kad pagrindinis šiltnamio efektą sukeliančių dujų emisijos iš javų auginimo šaltinis Lenkijoje yra azoto trąšos. Taip pat nustatyta, kad didejjant agrotechninio intensyvumo lygiui, auginant daugumos rūšių javus, šiltnamio efektą sukeliančių dujų emisija grūdų produkcijos vienetui didèjo. Daugeliu atvejų tai vyksta dèl augalų pertręšimo azotu.
\end{abstract}

Reikšminiai žodžiai: azoto dioksidas, azoto suboksidas, emisijos neapibrěžtumas.

Please use the following format when citing the article:

Wojcik-Gront E., Bloch-Michalik M. Assessment of greenhouse gas emission from life cycle of basic cereals production in Poland. Zemdirbyste-Agriculture, 103 (3): 259-266 DOI 10.13080/z-a.2016.103.033 